\title{
BETWEEN THE CONCEIVED AND THE LIVED, THE PRACTICED: THE CROSSING OF SPACES AT THE ARTS AND CRAFTS FAIR OF NAMORADOS SQUARE IN VITÓRIA/ES, BRAZIL
}

\author{
Entre 0 concebido e 0 vivido, o praticado: 0 entrecruzamento dos espaços \\ na feira de artes e artesanato da Praça dos Namorados em Vitória/ES
}

\author{
Fabiana Florio Domingues* \\ Letícia Dias Fantinel** \\ Marina Dantas de Figueiredo***
}

\begin{abstract}
This article aims to understand how the organizational space of a fair (the Arts and Crafts Fair of the Namorados Square, in Vitória, Espírito Santo) constitutes itself as an intersection of uses that different subjects adopt in the urban space. For this, we used an ethnographic method, with the data produced from systematic and participative observations between May and October 2015. We examined the data based on categories created from the theoretical propositions of the authors Henri Lefebvre and Michel De Certeau. Results show that the organization of the fair is determined by provisional practices, whose existence is permeated by manifestations of power, resistance and conflict, which emerge from the daily life of the subjects. By revealing forces that act by forming ephemeral harmonies, we show the intersections of space that are conceived and lived. The fair, as an organizational form, emerges from the juxtaposition of uses and appropriations of its spaces, in dynamic relationships that privilege space concepts elaborated by certain subjects and sometimes by others.
\end{abstract}

Keywords: Organizational Symbolism. Space. Ethnography. Fair.

\begin{abstract}
RESUMO
Este artigo tem por objetivo compreender a forma como o espaço organizacional de uma feira - Feira de Artesanato e Artes da Praça dos Namorados, em Vitória, Espírito Santo - se constitui nos entrecruzamentos dos usos que diferentes sujeitos elaboram para o espaço urbano. Para isso, utilizou-se o método etnográfico, com produção dos dados a partir de observação sistemática e participante ocorrida entre os meses de maio e outubro de 2015. Os dados foram examinados à luz de categorias que articulam proposições teóricas dos autores Henri Lefebvre e Michel de Certeau. Os resultados apontam para a compreensão do organizar da feira como composto por práticas provisórias, cuja existência é permeada por manifestações de poder, resistência e conflito emersas no cotidiano dos sujeitos. Ao revelar forças que atuam formando harmonias efêmeras, evidenciamos os entrecruzamentos do espaço concebido e vivido da feira. A feira, enquanto forma organizativa, emerge da justaposição de usos e apropriações de seus espaços, em uma dinâmica que privilegia ora concepções de espaço elaboradas determinados sujeitos, ora por outros.
\end{abstract}

Palavras-chave: Simbolismo Organizacional. Espaço. Etnografia. Feira.

* PhD student in Administration at the Graduate Studies and Research Center in Administration of the Universidade Federal de Minas Gerais (CEPEAD/UFMG). CNPq scholarship holder. Master of Business Administration at the Universidade Federal do Espírito Santo (UFES). Email: fabianafd@gmail.com. ORCID: 0000-0003-4791-7070

** Professor of the Graduate Program of the Universidade Federal do Espírito Santo (PPGAdm/UFES). PhD in Administration at the Universidade Federal da Bahia (UFBA). Email: leticiafantinel@gmail.com. ORCID: 00000002-4589-6352

*** Associate Professor of the Graduate Program in Administration of the Universidade de Fortaleza (PPGA/ UNIFOR). PhD in Business Administration at the Universidade Federal do Rio Grande do Sul (UFRGS). Email: marina.dantas@gmail.com. ORCID: 0000-0003-3273-8176 


\section{INTRODUCTION}

T

he urban space is made up of a set of different uses that social groups adopt in the city. Its complexity imposes challenges on research, since the understanding of urban dynamics entails identifying and capturing the integrations of commonly stressed political and social interests. Although traditionally studied from the functionalist point of view (VIEGAS; SARAIVA, 2015), the city is full of symbolisms that permeate its physical and social configuration. The various appropriations that social groups make of city spaces reveal the many ways of perceiving and creating the world (DAMASCENO, 2007). Understanding the city as a phenomenon created and recreated by the subjects that participate in the urban space requires thinking about its inhabitants, perceiving them in their varied forms of existence and including them in the material and symbolic construction of the city.

Although urban spaces are produced and reproduced according to the geographic, political and cultural characteristics of cities, it is common for certain organizational forms - formal or informal, symbolic or constructed - to be present in almost all of them. These organizations constitute the public space and play a diverse role in the provision of services to urban populations. Among these functions is commerce as a social and economic activity that produces transformation in the physical and symbolic space of cities.

For the purposes of this work, we highlight fairs (or markets) as a privileged object for the investigation of the dynamics of urban space. As ancestral organizational forms that are still present in various human societies, fairs can be considered emblematic not only for commercial activity, but also in the relation to the city and its cultural and social diversity (FERRETTI, 2000; FILGUEIRAS, 2006; SOUSA, 2000). In Brazilian cities, fairs originated from the Iberian tradition, later they mixed with African and indigenous practices of trade and commerce, resulting from a long process of modification into open-air markets (MOTT, 1976; 2000). Functional overlays of the urban space are evident in the fair, which can also be taken as a focal point to understand how the intersections of social and symbolic uses and appropriations of the city by social groups constitute the organizational spaces.

In the field of Organizational Studies (OSs), fairs are still not very explored as an empirical object. Some studies in the Brazilian context have already approached different urban fairs from the perspectives of identity (CARRIERI; SOUZA; LENGLER, 2011; PIMENTEL; CARRIERI; LEITE-DA-SILVA, 2007), organizational practices and strategy (CARRIERI et al., 2008; DE SOUZA et al., 2014; PIMENTEL et al., 2011) or as spaces of vitality (FILGUEIRAS, 2006). Along with these contributions, we highlight the originality of investigating the relationship between the fair as an organization and the dynamics of the city. We understand that the fair as an organization, with its complex and multifaceted characteristics (HERNES, 2004), allows us to unveil economic, social and symbolic structures that are embedded in urban dynamics (FERRETI, 2000).

In view of this, we seek to study the constitution of the organizational space, in relation to the dynamics of urban space. Our objective is to understand how the organizational space of a fair - the Arts and Crafts Fair of Namorados Square, in Vitória, Espírito Santo - constitutes the intersections of uses that different subjects elaborate for the urban space. 
We adopt a symbolic approach (HATCH; CUNLIFFE, 2013), according to which the organization itself can be seen as the confluence of subjectively elaborated symbols, narratives and constructions of sense. Congruent with this definition for the organizational phenomenon is the ethnographic method (CAVEDON, 2008; CHIESA; FANTINEL, 2014), adopted to investigate symbolic aspects and manifested representations of the appropriation of the public space by the different subjects who experience the fair every day. From the ethnographic perspective that we adopt, we seek to approach the fair and its spaces as an experience (TAYLOR; SPICER, 2007; TOMKINS; EATHOUGH, 2013), positioning this study from a comprehensive perspective, in which the role of research is to interpret the meanings, perceptions and experiences circulated and engendered in the organizational universe, adding symbolic and material perspectives.

We understand that the present research presents a relevant contribution as it proposes the investigation of an already traditional fair in the context of the Capixaba (originating from Espirito Santo) capital, which integrates, in its different spaces, inhabitants of the city and the neighboring region, tourists, representatives of public power, artisans and traders. Such a multiplicity of subjects, experiencing the spaces of the fair, do this by building and rebuilding it symbolically, from contexts of different conceptions, experiences and practices, which we understand to be the intersections of spaces. Thus, socially constructed spatial realities reveal different meanings, practices, and interests that sometimes come together, forming a complex kaleidoscope of intersubjective consciousnesses, which at times tend to conflict, and at other times combine harmoniously, in a heterogeneous, fluid and fragmented manner.

The way to construct such interpretations demonstrates another contribution of this article, in that it articulates emerging perspectives in the analysis of the organizational space (WATKINS, 2005). We show the potential of the theories of Henri Lefebvre and Michel de Certeau to understand the material and symbolic dimensions of urban space produced by the experience of its inhabitants. We start from Lefebvre's spatial triad for the integrated understanding of the domains of space as planned, conceived, and of space as lived every day. Nevertheless, the articulation between the conceptual spheres of Lefebvre is done through a dialogue with Michel de Certeau's thought on the practices of space. The analysis was built, therefore, linking the practices to the spaces and symbolisms produced, which enabled us to understand the process of organization as composed of provisional practices, in which manifestations of power, resistance and conflict emerge, constantly re-signified by the subjects so that the organization of the fair could happen.

So, we invite the reader to follow the path that we go through in the fair, whose narrative is organized in the following sections: after this introduction, we present the theoretical reference, followed by the methodology, the presentation of the field, and, in conclusion, the final considerations.

\section{SPACE AS EXPERIENCE: SITUATING THE PERSPECTIVE OF OSS}

In the field of OSs, aspects related to spaces and spaialities in organizations have been the focus of research by different investigators (DOVEY, 1999; KORNBERGER; CLEGG, 2006; CLEGG; KORNBERGER, 2006; VAUJANY; MITEV, 2013). In 2010, Van Marrewijk 
and Yanow (2010) even talked about a "spatial turn" in the field, highlighting the paths of analysis about organizational space and work space that dated back at least 30 years before.

Space has been recurrently addressed by management theories, since it is the scene for actions in organizations (CHANLAT, 2006). However, it was from the theme of organizational culture in the 1980s and 1990s that the spatial and material aspects of organizational life came into focus. This "spatial turn" followed the movement that occurred concurrently in other social sciences, such as philosophy and anthropology. By rediscovering space and spatiality, this new focus has brought OSs closer to a long tradition of space studies in the fields of human and social geography, city studies, urban planning, and sociology.

Taylor and Spicer (2007) classify research on organizational spaces into three basic approaches: space as distance, space as the materialization of power relations, and space as experience. The first category corresponds to a strictly physical perspective of space, considered as the distance (possibly measurable and objectively represented) between two or more points. This approach, which can be taken as the most common understanding of space in organizations, is present in a broad set of works based on functionalist perspectives on organizational phenomena. In this paper, we will focus on the relationship between strategy and organizational space (GIBLER; BLACK; MOON, 2002; DAMERON; LÊ; LEBARON, 2015).

The category of space as a materialization of power relations addresses the issue of control, surveillance and discipline in and out of an organizational setting, as in the discussion of urban spaces (TAYLOR; SPICER, 2007). From this perspective, the space provides fixed positions or allows for circulation, marks places, defines actions, guarantees obedience in arrangements that reflect and reproduce hierarchies and power relations. Particularly relevant to the grouped approach in this category are the studies that seek to understand the places of power in organizations (FLEMING; SPICER, 2014), which are symbolic in relation to physical space. The mutual implications between architectural space and management are the subject of reflection for the OSs (KORNBERGER; CLEGG, 2006; KERR; ROBINSON; ELLIOT, 2016; VALAND, 2011; VAUJANY; MITEV, 2013). In this approach, one can perceive the theoretical influence of Michel Foucault's concept of disciplinary power (CAIRNS; McINNES; ROBERTS, 2003) and an empirical orientation aimed at the observation and interpretation of space and material culture in relation to the interactions and understanding of behaviors of subjects in situ (O'TOOLE; WERE, 2008).

Finally, the category that addresses space as experience is concerned less about aspects such as distance and proximity or even power relations but focuses specifically on how spaces are produced from the experiences of those who appropriate and inhabit them. Thus, space as experience starts from a comprehensive perspective, in which the role of research is to apprehend and elaborate ways of communicating the meanings, perceptions and experiences circulating and engendered in the symbolic organizational universe.

The approach of space as experience is characterized by the adoption of a subjectivist ontology (HATCH; CUNLIFFE, 2013), according to which it is understood that reality is conditioned to the subjects' experience and their ways of elaborating meaning from experiences. From interpretive (PUTNAM; BANGHART, 2017) and phenomenological perspectives (TOMKINS; EATHOUGH, 2013), the currents of thought of OSs dedicated to this understanding of space and spatiality have assumed that the spatial reality of organiza- 
tions is socially constructed, which makes sense in the context of the subjects' experiences. According to this approach, it is understood that symbolic constructions about organizational space tend to settle on existing physical structures, such as buildings, rooms and offices, which are exactly the places where the organization develops.

In this approach, one has the understanding that organizational space emerges as a product of intersubjective consciousness, from experiential contact with space. In this way, the existence of the organizational space is elaborated from concrete material references, which gain meaning through symbols, representations and constructions of meaning, but mainly through communication processes (ROPO; HÖYKINPURO, 2017; VÁSQUES, 2016; WILHOIT, 2016), and by the non-representational path of performance (BEYES; STEYAERT, 2011). This approach poses challenges to organizational research and points to the adoption of phenomenological ideas (TOMKINS; EATHOUGH, 2013), which elaborate the understanding of the experience of space in the flow of life.

\section{THE SYMBOLIC PRODUCTION OF URBAN SPACE}

The emergence of space as experience is largely due to Lefebvre's work (2006). In The Production of Space, the author adopts a critical epistemology to define social space as a concept that cannot be isolated, nor remain static, since it arises from a set of dialectic relations of production/reproduction. In order to elaborate this dynamic concept of space, everyday life appears as a central force, according to commentators on Lefebvre's work (ELDEN, 2004; KIPFER et al., 2008). In his understanding of space, Lefebvre (2006) emphasizes the generative potential of everyday interactions and his method of work can be described as an observation of everyday life, in search of experiences that produce space from the perspective of social subjects (BEYES; STEYAERT, 2011). According to Lefebvre (2006), space can be both abstract and real, concrete and instrumental, and also transcend its own instrumentality. For the author, space can be conceived beyond its materiality, being associated with social reality, that is, it is socially produced (LEFEBVRE, 2006). Thus, the human being, while living in society, builds and rebuilds his physical, social and cultural world.

The experience of space is also a resource in the thoughts of Michel de Certeau. In the work The Practice of Everyday Life, the author contributes to the theory of action by placing the focus of his studies on the creativity of the subject, by dedicating his analysis to the interstices with which the individual escapes from what is expected of him/her (COVA, 2014). In this work, Certeau (2014) analyzes, dialectically, apparently insignificant cultural practices of daily life from the logics that sustain them (BUCHANAN, 2000). Thus, since Certeau (2014) explores the processes of bricolage and appropriation as expressions of counter-power of the ordinary person, his work succeeds in giving some measure to the central question that Lefebvre shared with the thinkers of his time: "how to get out of daily life?" (COVA, 2014). That is, how to understand the theory-practice relationship beyond common sense but having to recognize that this is the theoretical resource of the social scientist. 
According to Lefebvre (2006), space can be conceptualized in (at least) three different ways: the space conceived, the lived space and the perceived space ${ }^{1}$. The space conceived is related to the space of the dominant mode of production in a society, which tends, most of the time, to be "a system of verbal signs, and accordingly, intellectually elaborated" (LEFEBVRE, 2006, p. 66). Meanwhile, the lived space is the space of the inhabitants, permeated by images and symbols; "It is the dominated space, in which the imagination tries to modify and appropriate," resembling "more or less coherent systems of nonverbal symbols and signs" (LEFEBVRE, 2006, p. 66). The thinking of the author, highlighted by rightly demonstrating the dialectical dimension in the understanding of space, in a constant intersection of materiality and representation, problematizes the urban space in terms of processes that consist of its progressive secularization and commoditization (WILSON, 2013).

According to Lefebvre (2006), the production of space can be understood through the combination of three elements: the practice of space, representations of space and spaces of representation. Certeau (2014), in turn, refers to space as the place practiced - that is, produced ambiguously from the relationship of the subject with the world, in its spatial existence. Comparatively for the author "reading is the space produced by the practice of the place constructed by a system of signs - a writing", which is constituted in everyday practices (CERTEAU, 2014, p. 184).

What we propose here is the intention to highlight the dynamics of material and representational interlinkages, especially through the symbolic dimension of urban spaces in relation to organizational spaces. In this sense, the conceptions problematized by Certeau (2014) are essential, in that the author unveils mechanisms of transformation and significance of the spaces stemming from everyday practice, by the appropriation of these same spaces. Equally important for this understanding is the contribution of Lefebvre (2006) on the forms of production of the urban space in relation to the production work of different social groups. In the encounter between these two theoretical strands, the idea is that the produced spaces and places produce people at the same time that they construct them (DALE; BURRELL, 2008). It should be observed that this understanding is only possible from an analysis that is not only relational but also historical, taking into account facts, relevant conflicts and power relations in each situation.

It is important to emphasize that the very notion of everyday life for the authors is different, considering that for Lefebvre, the forms of domination that arose within modernity -understood from the angle of consumption - constitute forms of alienation, whereas, for Certeau, this same consumption represents situations of resistance that allow the subject to put into practice their tactics and the arts of making (COVA, 2014). Likewise, notions of space diverge, as we have already mentioned. However, we agree with Cova (2014), where light is shed on the proximity of at least two notions used by both authors: use and appropriation. While Lefebvre proposes to rehabilitate the concept of citizenship in the practices of use, since he perceives, in everyday life, the reproduction of the relationships of dominance, Certeau suggests taking another look at the individual, demonstrating creativity,

1. We chose to work with only the first two categories of space because we understand that the conflicts that emerged in the field reveal, to a greater extent, the tensions between what was conceived and what was experienced at the fair. In this sense, we prefer in this article not to go deeper into the category of perceived space. 
not passivity (COVA, 2014). Both, then, deny the idea of an individual manipulated by the system. Likewise, Lefebvre incorporates appropriation into the field of practice, although he does not consider processes of re-appropriation to be acts of creation, unlike Certeau (COVA, 2014).

Nevertheless, despite the disagreements, we understand that in the subject's experience of inventing the world from their use, dynamically creating and re-creating everyday life, that the propositions of space of both authors can be seen as complementary in the analysis of the field data gathered in this research. This possibility of dialogue is evident to the extent that we conceive that the transformation of space conceived into space lived (LEFEBVRE, 2006) occurs through the everyday practice of space by the subject (CERTEAU, 2014). The space, for Certeau (2014), is a place practiced, produced from the relationship of the subject with the world, personalized as a "movement", a stage of actions and representations of the subject in their daily life.

Henri Lefebvre, perhaps more than Michel de Certeau, is an author whose writings are often appropriated into the field of Geography and Urban Studies. Still, the thinking of Michel de Certeau can bring contributions to the study of urban dynamics, especially in the problematization of practices and appropriations of space by ordinary people, who experience and produce the urban every day. In this sense, while produced socially, the urban space is constructed as the stage for the spaces of representation (LEFEBVRE, 2006). These spaces of representation go beyond mere geographical paths to be travelled at random; the representations underlying the production of urban space carry notions of intentionality, which characterize the conception of space, as it is constituted from the uses of the subjects (SANTOS, 2006). Thus, it is not possible to think of the city only physically, as an inert environment, leaving out approaches that do not consider the socio-spatial practices that shape and construct it (CARLOS, 2007). The social practices in space develop as performances of the subjects, that is, as the outcome of their sensations and of their corporality in relation to the experience of the environment (BEYES; STEYAERT, 2011).

Going deeper into the idea of experience, we understand that human action in the different urban landscapes is marked by a social corporality (SANTOS, 2006), perceptible in its materiality in the residential and commercial configurations, in the architecture and constructive patterns (DALE; BURRELL, 2008), in the distribution of people and buildings, and in the physical layout of the city (SANTOS, 2006). The different architectural constructions present in society are loaded with symbolisms that seek, through humanity's need to situate their world in time and space, to leave messages of their understanding (DALE; BURRELL, 2008). The formalized actions of planning of the city are defined, therefore, by the city that is desired, from a conception produced from a place of specific power. However, it is important to emphasize that the conception of space is in the field of images, while the real is in the dimension of the experience of this space, given through its everyday appropriations (CERTEAU, 2014). Between the planned and the lived, the urban space is redefined in processes of appropriation, by the individuals who develop their practices of representation in the social space.

To take possession of a space means to take a certain place as "yours", attributing to it characteristics of personal or social identification that demonstrate the interaction of people with the different environments (FISCHER, 1994). Still according to Fischer (1994), 
the dynamics of appropriation are never neutral, since they carry with them different cultural marks that give meaning to the space. Thus, the materialization of the process of socio-spatial practice occurs in the "realization of the social relationships that produce the places, this is the dimension of the production/reproduction of space, which can be seen, perceived, felt, lived" (CARLOS, 2007, p. 21). This is because it is in this appropriation of space that the reproduction of society is based, in its uninterrupted sense of lived life, revealed in a set of relationships, behavioural models and value systems (CARLOS, 2007; IPIRANGA, 2010).

From the concepts presented here and the interweaving of complementary perspectives of space, in the next item, we present the methodological routes covered in this research.

\section{METHODOLOGICAL ROUTES}

According to the theoretical approach of space as experience, we chose to carry out a qualitative empirical research on the fair of Namorados Square, understanding that this allows us to understand the subjective, present in the space investigated. In this context, we seek to understand how the fair is constituted by the intersections of uses that different subjects attribute to the urban space, in their everyday practices that develop as performances in space (BEYES; STEYAERT, 2011). We took the ethnographic position as guided by a phenomenological experiential perspective (TOMKINS; EATHOUGH, 2013).

Thus, at the beginning of May 2015, one of the authors entered the field and began to use participant observation, which lasted until the middle of October of the same year. From the field insertion, 40 dense and detailed field diaries were written to record, based on the recommendations of Cavedon (2008), their feelings on the day of the study, in addition to the observations of the researcher. Following the premises of the method, the actions in the field were based on trying to maintain the position of ethnographer, by being attentive to the conditions of knowledge production expressed in the interactions and reflexivity that are integrated in the field of research (CHIESA; FANTINEL, 2014).

As a strategy for approaching the subjects, this author offered help to the stall holders, in exchange for conversation (and information). Thus, the researcher in the field offered to the respondents help to load the products, set up stalls, install lights, carry ice, set up canopies used to protect customers from rain, whatever was necessary. These actions throughout the research refer to the importance of a proactive behaviour on the part of the researcher in the search for data following the principles of ethnography, as proposed by Cavedon (2014). Thus, the function of "doing anything that shows up" provided the flexibility to get to know and participate in activities in different stands (food, handicrafts and bric-a-brac or "fuleragem"2), which allowed for a better understanding of the different dynamics, diversifying the ways to look and the construction of the polyphony of the text.

Data from the observations, field diaries and interviews were interpreted in the first instance by the researcher, who is the first author of this text, in the light of theoretical

2. "Fuleragem" is the term used by stall holders themselves when referring to products purchased from popular markets in São Paulo and Belo Horizonte, products which are mostly from China. It has the connotation of being "fuleiro", which is a slang adjective to refer to cheap imitations. 
reference and field experiences. The other authors interacted with the field data, read the analyses elaborated by the researcher and offered secondary analyses, guided by the theoretical reference and the evidence of the theoretical contribution of the empirical work. We chose this form of analysis because we understand that, although ethnographic research is the result of an individual effort, the production of theoretical reflections in regard to field data can be enriched by collective work. This way of treating empirical data has the potential of strengthening the reliability of the findings, as well as increasing the legitimacy of ethnographic research in OSs, since the researcher is led to question how his subjectivity guided the empirical findings, through the contact with the other researchers. The report of the field experiences follows the shared logic of authorship assumed in this text, complemented by the adoption of the first-person plural as the pronoun of choice in the presentation of empirical data.

\section{INTRODUCING THE FIELD: THE FAIR ORGANIZATION}

The Fair of Handicrafts and Arts in the Square - popularly known as the Fair of Namorados Square - is located on the Do Canto Beach, considered, according to the City Hall, as one of the regions with better infrastructure in the city, with good commerce and services (VITÓRIA, 2015). According to the 2010 Census figures, the neighbourhood is the third most populated in the city, with about 15,147 inhabitants of the 327,801 inhabitants of this capital. The per capita income of the residents of the neighbourhood was, in 2010, around $\mathrm{R} \$ 3,844.97$ (monthly average), compared to $\mathrm{R} \$ 1,662.97$ for the whole city (IBGE, 2010). The landscape is noticeable for its imposing constructions and high residential and commercial buildings.

The square has two tennis courts, a volleyball court and a sand soccer court, a skate park and a children's playground. The square also has green areas and several trees of different species, which guarantee enough shade. There is also 24-hour CCTV, as well as being a route for the military police, municipal guard and mounted police to pass through inpreventive actions. The fair takes up an area of $5,901.94 \mathrm{~m}^{2}$ for its operation, about $50 \%$ of the area of Namorados Square, being set up in the late afternoon and evening regularly on weekends and sporadically on public holidays or commemorative dates. The fair is also part of the Arts in the Square Program, an initiative of the Municipality of Vitória (City Hall), which has existed since 2004 (VITÓRIA, 2015).

There is a lot of miscommunication about when and how the fair began; however, according to some sources, the fair was recognized by local authorities in the second half of the 1980s. Initially local and handicraft products were the "flagship" products of the fair, but over time, other stalls were set up and sold a variety of products. Passing through the stalls of the fair, one can notice a great diversity of handicraft products, as well as industrially manufactured products such as toys and silverware, that are bought from other popular markets, generally in São Paulo and Belo Horizonte, "made in China" being the vast majority. There are also food stalls selling typical regional dishes, such as moqueca and capixaba, but other fast food options such as Mexican, Japanese, Bahian, pizzas and the ever-popular skewers are also available. 
It is appropriate here to present the aspects of the physical structure and the formal organization of the fair. Although the fair usually starts late in the afternoon, the mobilization of the workers starts long before that. On weekends, early in the morning, we can already see the movement of the assemblers in the square. Exhibitors start arriving after 2:00 p.m., and soon after 4:00 p.m. some of them are already organizing their products on the tables (each exhibitor has his or her own time to set up and organize their stall, at the pace he or she considers most appropriate). Closing times also vary, depending on the number of customers.

Some physical elements demarcate the boundaries of the organization. For example, the sound system. Around the square, fixed onto some posts, it is possible to see speakers, which are operated by one of the exhibitors who, besides being part of the management committee, is also part of the management of the association. The fair therefore has its own sound system, from which diverse music is played and, like a conventional radio, it is also an open space for advertisement. The commercials advertise the different products sold on the stalls. Along with the adverts, songs are played that are intended to allude to the type of product sold. Among the commercials, diverse musical genres are played, which is also cause for conflicts, due to the diversity of musical tastes of the exhibitors.

Another physical element that delimits the fair is the lighting. In addition to the street lighting posts in the square, the lighting of the space is reinforced by the illumination of the stalls, for which, the responsibility and costs are covered by the City Hall. For the exhibitors, there are power distribution boxes with sockets, covered by a metal cover, arranged on the floor, around the whole square. After the change of layout in 2015, which will be dealt with later in this article, some of these boxes moved even further away from the stalls, requiring that the exhibitors increase the length of the electrical extension cables they used, causing the electric wires to cross on the floor, in the way of the pedestrians.

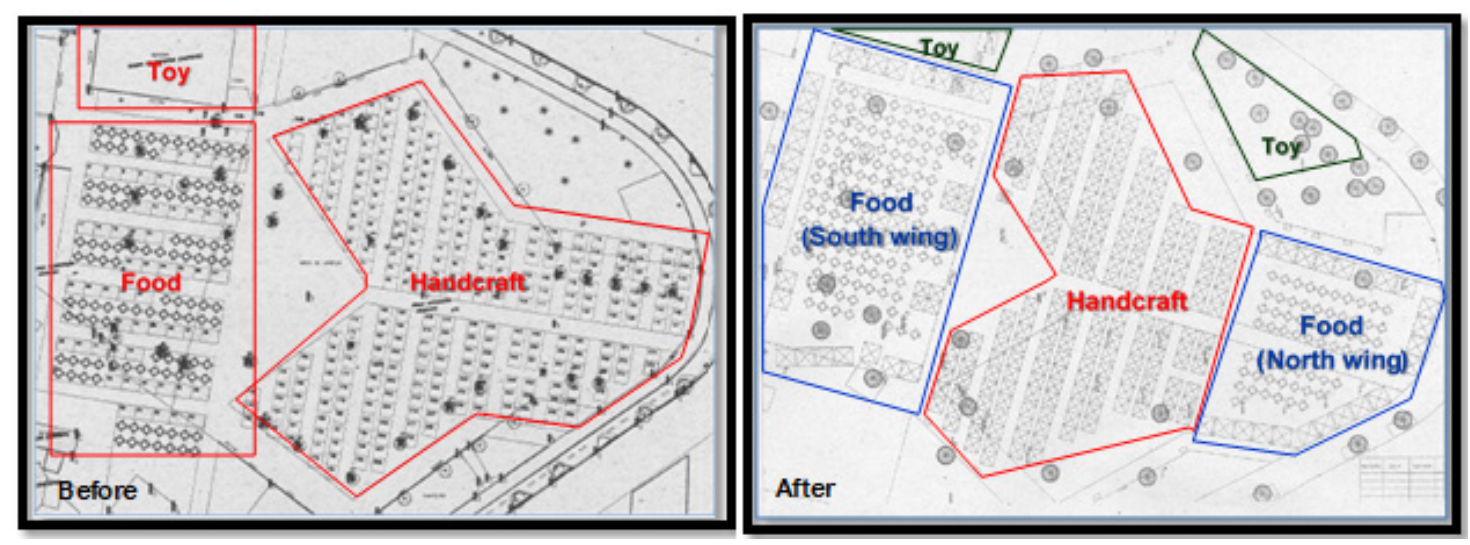

Figure 1 - Layout of the fair, before and after the change

Source: City Hall of Vitória, 2015.

Besides the sound system and lighting, the most noticeable physical element of the fair organization is the way it stands in the space of the square. The distribution of the stalls in the square can be delimited and represented in a drawing, which we call a layout, 
in accordance with the emic language. In September 2014, the layout of the fair - which concentrated the food stalls at one end of the square - was altered, implying a new social corporeity (SANTOS, 2006) to the spaces, as they were reconfigured materialities that, according to conceptions produced from a place of power (DALE; BURRELL, 2008), have generated concrete consequences in the ways of experiencing the fair, both by the exhibitors and by the passers-by. The new layout of the stalls was designed by the City Hall, who distributed the food stalls on both sides of the square, concentrating the handicrafts in the middle, as shown in Figure 1. This change was seen as necessary by the subjects in the field, who were the representatives of the management committee, the City hall and the exhibitors, since, according to them, it polarized the public's access to food stalls.

This intentional change in the fair's materiality caused changes in the distribution and flow of people. According to the exhibitors themselves and also in the opinion of the assemblers of the stalls and City Hall, the change increased the circulation of people at the fair. During the field research, it was possible to observe a greater movement of people from one place to another in the square, something that was not noticed in the previous layout, in which the people remained in the area destined for eating. Thus, it is possible to say that the reallocations forced changes in the ways of experiencing the spaces of the fair by different subjects. Such a change displeased many merchants, especially the food merchants, who had to leave the space they had previously occupied and which their customers were already familiar with, to set up elsewhere. Some exhibitors, while still recognizing the importance of the changes, realized that new conflicts among exhibitors emerged from the changes, especially in those whose new experience of the spaces was perceived as harmful.

Regarding the formal planning, at the time of the research, according to City Hall information, the fair consisted of 209 stalls, being 159 for handicrafts and toys and 50 for food, as well as receiving between 5,000 and 8,000 visitors on the weekend. Some exhibitors are organized in an association, but it should be noted that this membership is not homogeneous. Among some, the opinion that prevails is that the association exists for the benefit of the few, not meeting the expectations of the majority. The so-called management committee (whose existence is required by City Hall) is made up of three exhibitors - one of food and the others of handicrafts or toys - with three substitutes. Every two years, a new management committee is elected, in a voting process among the members. It is the management committee that mediates the needs and demands of the exhibitors with the Municipal Secretary of Tourism, Labour and Income (Semttre).

It is in this scenario, in which we understand space as experience, produced from the different uses that are made of it every day, we focus on the different conceptions of space and understanding of what is or should be the fair, which reveal symbolisms constructed and reconstructed in dynamics that can both approximate or distance exhibitors and visitors. These points of consensus and dissent, which can be seen in the day-to-day dynamics of the fair, are presented below, based on the categories of analysis emerging from the data produced in the field. 


\section{THE PRACTICE OF SPACE REVEALING ITS INTERSECTIONS}

As already articulated theoretically in this article, the practices of spaces (CERTEAU, 2014) emerge from the experiences of the different subjects that modify and appropriate these spaces, so that the conceived meets the lived (LEFEBVRE, 2006), in existences that transcend limits and transgress the established order. Thus, there is the construction of an intense re-appropriation and re-signification of the spaces, produced from the experiences (TAYLOR; SPICER, 2007) of exhibitors, fair visitors and public authorities.

It is worth mentioning that we use here an intentional blending of the categories of square and fair, expressed by what we interpret as an interdependence between the two signs, converting them into complex symbols that are related and confused, in a square that enables the existence of the fair and a fair which gives meaning and life to the square. So, after this explanation, we present the results of the field research and the revelations of the fair.

\subsection{MANY SHOPS AND SHOP WINDOWS: THE SPACE DESIGNED FOR WORK, INCOME COMPLEMENTATION AND INCOME GENERATION}

According to a source, the Fair of Namorados Square was conceived by the City Hall as a way to both accommodate the informal workers who occupied another square in the centre of the city of Vitória, as well as to control the use of this public space (according to the source, City Hall "understands as the main importance [...] the need for a little control [...] actual control of spaces [...] I don't really like that word, but it is inevitable [...] It is part of the organization"). We can insert into the dynamics of the fair, the people who work there to complement their salary or generate income; the inhabitants of the city and surrounding areas, who gain an additional leisure option; the agents of public authorities, who represent the city planning, all of these combined with the plurality of lived spaces. With such dynamics, it is possible to perceive the intentionality present in the conception of the fair, which sought to shape the physical spaces (CARLOS, 2007; LEFEBVRE, 2006) of Namorados Square.

As well as the public power, the exhibitor also designs his/her fair, based on meanings related to his/her place of work, or even an opportunity, even if modest, to own their own business. In this way, they elaborate for themselves strategies of use and appropriation of their space in the fair. Also, the visitors have their own conception of the fair. There are different perspectives that denote the way in which subjects attribute various meanings and representations to the uses of spaces, which transcend the materiality of the city (FISCHER, 1997; IPIRANGA, 2010).

The fair as a space for work, salary complementation and income generation, as conceived by the City Hall, can be reinforced by the account of many exhibitors who tell similar stories about how they came to be there. During the field research, multiple narratives of exhibitors were registered, in order to justify their presence at the fair: unemployment at a given moment in life, the desire to restart after a debilitating accident or maybe, the 
beginning of a new life in a foreign country. In common, there is the will to work and the need to support themselves and their families.

These trajectories and strategies (CERTEAU, 2014) reveal an intellectual elaboration of space (LEFEBVRE, 2006), which, in an urban context, transforms itself according to social constructions and reconstructions on the part of the public authorities, workers and local population. Such planning seeks to act as an organizer of activities as a kind of spatial advisor, that is, in representations that seek to define in discourse the uses and appropriations of space (LEFEBVRE, 2006).

Although not all of them had previously planned to become exhibitors at the fair, many of them have appropriated such a profession, which often merges with that of craftsman. In search of opportunity, many exhibitors at the fair ended up finding in it a means of making money and a place to work, or, as many like to say, "display their work". For most of the exhibitors who were the subject of this research, work at the fair is their only source of income; for others, it serves as a complement to their income or retirement pension. The sense of place of work conferred to the fair refers to the meanings and appropriations described by Fischer (1994), in which the subjects take over the space of the fair, reassigning meaning to the square itself.

The fair symbolizes for these workers a new beginning, the opportunity to work and to have a way to support themselves. However, the data obtained in the field reinforce Sousa's (2000) argument, when he suggests that the fair is not only a means to make financial gains, but it also offers the possibility of this being the result of a pleasant work, practiced in the direct relation between producer and final consumer without the mediation of a middleman. Farmers with whom the field researcher had contact had different meanings for "owning their own business": to plan, to produce and to sell, to have their own store and to manage it in their own way.

We also note that, for the fair workers, it is not just a question of financial matters. According to those surveyed, being at the fair involves meanings like exploring your own potential, offering yourself the opportunity to work independently, at your own pace and in what you know and appreciate doing. However, this does not mean that the choice of the fair as a way of life does not involve hard work, as the exhibitors report working more than 14 hours a day making the products they sell at the fair on weekends. For exhibitors, the space they occupy in the square is their store and the stall is their shop window. For this reason, each one has his or her way of arranging it, and many show annoyances with passers-by who do not demonstrate the same care for the products when touching them. There is the ritual of assembling and dismantling the store every day of work, which is carried out with much fondness in order to "catch the eyes" of the bystanders.

The regulations that determine working conditions at the fair provide for one month's vacation to the exhibitors, but many said they had never been away from the fair for many days, because "the secret is not to stop coming [to the fair], as in a store, if you aren't open you don't sell "(Field Diary, 06/27/15). Thus, there are exhibitors who prefer to keep the stall open even in their spare time, for fear of losing the connection with the clientele, or fear of not earning anything for a long period. It is interesting to point out that the understanding of the stall as a store (a meaning that implies a notion of perenniality) on the part of the exhibitors contrasts with the conception of the fair as a temporary work, that 
would serve as a "springboard" for the insertion into the labour market or as the beginning of an entrepreneurial career. This second view was expressed by the City Hall in interviews, indicating divergent conceptions of space.

This space as a place of work, income complementation and income generation, as conceived by the City Hall, presents itself as a strategic organization for sharing of work and leisure, a conception that is often altered by the tactics expressed in the ways of doing by the subjects. Certeau (2014) points to a strategy as something that creates abstract places capable of producing, mapping, imposing; while tactics have no other choice but to use, manipulate, and alter these places, since, in the author's words, "tactics have no place other than that of the other" (CERTEAU, 2014, p. 94). In this way, what we see is a relationship of forces in which strategy and tactics are articulated in the detailing of the daily life of the fair. A symbolic balance that reaffirms the appropriation of the urban space by human action in the different landscapes (SANTOS, 2006), which enables understandings between material reality and social relations, as well as demonstrating contradictions in social movements and practices (CARLOS, 2007).

In this way, the space of the fair was conceived for representations of space, those related to knowledge, signs and codes (LEFEBVRE, 2006), which becomes evident in the narratives expressed by the public authorities, which conceive the fair for certain purposes. This typification of the space was conceived by the City hall and exhibitors as a place of work and income generation, which sometimes conflicts with or complements the conception of the society that sees the fair as a leisure space (even if it is free leisure characterized by a walk in a public place). Whenthe City Hall reaffirms the design of the fair as a temporary path for the exhibitor, which, in its view, should aim for another type of future business, or when preferring the term "passer-by" instead of "customer" it opposes the space conceived from the fair as the lived space, insofar as they ignore the space practiced and experienced daily by the subjects. This will be presented in the next topic.

\section{2. "NAMORADOS SQUARE IS NOT A SHOPPING MALL": THE SPACE LIVED AMONG FRAGMENTATIONS, CONFLICTS AND DISPUTES}

Living space is the place of experimentation in human life (LEFEBVRE, 2006), and for this reason cannot be stable, perennial, it is not bound to time or space. On the contrary, due to the subject's interaction with the world, in his or her spatial existence, ambiguities, contradictions and conflicts appear in his or her daily life (CERTEAU, 2014). Such interactions, given through practices and appropriations (CERTEAU, 2014), result in dynamics that are not neutral (FISCHER, 1994), but rather revealing of powers, interests and visions of the world.

As in other organizational forms, conflicts are present in the daily life of the fair. In certain situations, the clashes occur explicitly, as in the discontentment of exhibitors with the actions of the City Hall, and in others, in a veiled way, especially when related to the decisions involving the association and the management committee or the performance of competitors at the fair. 
As the working days at the fair passed by, the researcher in the field witnessed several conflicting situations among the exhibitors, such as the emblematic episode in which two artisans argued over a difference of ten centimetres in the positioning of their stalls. When faced with the refusal to move by his stall neighbour, who claimed that her clients needed enough space to admire her art comfortably, one of the artisans shouted: "Namorados Square is not a shopping mall, there aren't as many people who'd like to see her art!" (Field Diary, 07/26/15). On the other hand, there was the attitude of the exhibitor who refused to move her stall and showed great attachment to what she considered to be her own space. In her personal trajectory, beyond the "shared piece of ground", it was a great challenge to leave the "fabric" where she exposed, after 21 years working at the fair as a visitor, and earn the right to exhibit her art at a stall, like so many other exhibitors.

Moreover, the material arrangement of the fair, as with other organizations, acts so as to expose relations of power, established in the symbolic spaces of dispute, so that what is at stake is also the physical space (FISCHER, 1994). To be able to exhibit to the public by being on their way is interesting, but the symbolic appreciation of physical space occurs because of the socially produced space, an abstract space (LEFEBVRE, 2006), which cannot be understood objectively, nor for its utility or functionality. Thus, when analysing this situation in isolation, it is not possible to interpret the attitude of those involved and it is necessary, as we have seen, to understand the trajectories of these subjects.

Another interesting question, that appears in the speech of the exhibitor involved in the conflict, was the distinction he creates between the fair and the shopping centre, highlighting the inequality between the two realities, in which the former relates to the most popular commerce, marked by the relation of the city with its cultural and social diversity (MOTT, 2000; SATO, 2007). The latter, on the other hand, carries with it the notion of mass consumption, both of goods and services. To say that "Namorados Square is not a shopping mall" can be understood as declaring that there would not be a large enough public around a stall that would prevent it from being physically displaced to the point of affecting the well-being of potential clients.

Intermingled with such disputes, there is also the dissatisfaction of the exhibitors who consider themselves artisans with those who work with bric-a-brac (fuleragem), with which the exhibitor refers in a humorous way to the art of his neighbour. This aspect has shown itself to be involved in several situations of conflict between exhibitors, a context in which the dispute arises among artisans who consider that they are losing space to the bric-a-brac sellers. Exhibitors, regardless of their classification, are unanimous in recognizing that "before the fair was quite different," attesting to the change that has taken place over the years which brought the Chinese products to the square. We have to consider here the Chinese tradition in the trade of copies and cheap disposable items, which supply the Chinese desire to own foreign goods, and the country's own production and commerce system that is at the threshold of formality/legality and informality/illegality, where there is the status of opting for copies as an alternative in reducing imports. Originating from highly intensified production, these products reach all regions of the world, including Brazil. They have low prices and they allow for the formation of chains of distribution and resale, with the possibility of earnings for all those involved (PINHEIRO-MACHADO, 2009). 
Nevertheless, another issue of conflict, uniting craftsmen and bric-a-brac sellers, is the predominance of the sweet snack vendors who are the preference of the fair visitors. The general understanding is that people go to the market to eat and end up buying something else. The researcher had the same opinion, seeing that even on days with few sales, the food areas were always crowded. However, this is the minor dispute surrounding food vendors, as there are conflicts rising from their own competition with each other. The competition for the preference of the visitors occurs when there is the attempt to copy products that are already offered by another exhibitor, and when there is calling for attention in front of the stall, that is, in trying to be the same, as in the first case, and letting the customer decide at their own convenience what suits them. Or, as in the second case, when trying to be different.

In both situations, there is hostility among the sellers, which is sometimes disguised as the politics of the "good neighbour" adopted in the daily life of the fair with relationships that oscillate between cooperation and competition, a flow of actions and meanings in constant variation. This incessant search for symbolic delimitations, or spatial boundaries, forms symbolic barriers that transform and construct the fair every day (CERTEAU, 2014).

Thus, the conflicts between uses and appropriations of spaces at the fair are situational and fragmented, changing in a kaleidoscopic manner that combines conceptions and practices in a different arrangement for each situation. In addition, it is precisely by means of this complex combination that appropriations and uses of sometimes convergent spaces are demonstrated, often being divergent in relation to the different conceptions of space circulating in the fair, which unveil the articulation that makes possible the lived space. When we conceive of space as experience, we enable the unveiling of practices (CERTEAU, 2014) as a link that engenders space conceived and lived (LEFEBVRE, 2006), in the intersection of space that forms the fair.

\section{FINAL CONSIDERATIONS}

This article aimed to understand the constitution of the fair 's organizational space in the intersection of uses that different subjects adopt in the urban space. We therefore reiterate that the fair is an object of rich and contributory research for an OS. In the case of our study, it enabled us to highlight spatial realities that allowed us to unveil meanings, practices and interests. These, if understood under the light of emerging theoretical perspectives in the field, turn the findings and analyses undertaken here very relevant, Insofar as the organization of the fair is approached as composed of provisional practices, which allow for its existence through the manifestations of power, resistance and conflict emerging in the daily life of the subjects. This research, therefore, reveals different forces present in the space of the fair. Forces that act by forming ephemeral harmonies, which coexist in a tenuous symbolic balance, through which we can see the intersections of space conceived and lived in the fair. The fair, as an organizational form, arises from the juxtaposition of uses and appropriations of its spaces, in dynamic relations that privilege spatial concepts elaborated by certain subjects (such as representatives of the public authorities, for example), or conceptions elaborated by others (such as exhibitors or fair visitors). In these dynamics, symbolic divergences about the uses of the space of the square and the goal of the fair are concealed, silenced or solved, through practices that ensure ephemeral harmonies. 
In this sense, square and fair are confused and mixed in terms of their materialities and intentionalities, in the context of a square that allows for the existence of the fair and a fair that gives meaning and life to the square. The two signs appear as interdependent in the conversations taken from the field and in the very life of the subjects: workers, visitors, exhibitors and representatives of the public power, despite their different conceptions and experiences of space.

The different conceptions are perceived, for example, in the antagonism of the notion of the City Hall, when it declares the fair to be a temporary work space, while for exhibitors this is a lifetime's work. The space conceived by the City Hall is intercalated as temporary with the space lived as permanent by the stall holders. This divergence of perceptions undermines the idea of the fair as cohesive or homogeneous; in this way, what is seen, in certain moments, are subjects that act independently, often losing strength in their claims, which also impacts on the ways of experiencing space and living the work. These different visions of the fair give rise to conflicts among exhibitors - sweet snack vendors, artisans and bric-a-brac sellers - as well as between all of them together and the City hall.

As a form of resistance in relation to the pre-established rules, the subjects of this study appropriated the square and the fair each in their own way, challenging the location with its established strategies. Among the exhibitors, there are situations of discontent with the controlling body and the actions of those who, in their view, do not represent them satisfactorily, such as the management committee and the association. Thus, it is in the lived space in which individual stories develop in defiance of what is conceived during the appropriations and uses of daily life.

The fair of Namorados Square and its constructed spaces are constantly being redefined through the strategies and continuous and dynamic transgressions present in the daily space practices of the subjects of the research. These transgressions encourage the emergence of new strategies which, in turn, demand different tactics, in a continuum of lived space that resembles a game going through constant transformation, in an unclear differentiation between those who plan and those and those who live the fair.

In addition, it is in the intertwining of experiences of space that lies the marriage between strategies and tactics, conciliating the appropriation by everyone of the space of the square. A place invented in its conflicting, ambiguous conditions and contractual surroundings, sometimes becoming unstable, and because of this, enabling the production of the space of the fair. This instability, present in different spaces, is what makes the human world complex, challenging and at the same time impressive, allowing for a profusion of interpretations, all partial and situational.

Finally, we understand that in approaching space as an experience, our research clearly contributes to the field by unveiling not only the intertwining of conceptions and experiences of space, but also the very process of organization as being ephemeral and overlapping in the practices of spaces. However, it is important to note that this article is a section from a larger survey, and as such does not represent the totality of the data produced. Because of this, the focus of the research was on the subjects exhibiting at the fair and on the representatives of the public authorities, which is a limitation of the study. We do not go much further in this text in terms of the conceptions and experiences of the spaces 
of the fair by the visitors, for example, which were captured during the research, but due to the maximum length allowed for this article, we chose not to include.

In addition, we emphasize that it is still possible to advance in the problematizations developed here, in order to deepen the theoretical advance obtained from the study. Longitudinal studies, for example, may evidence the temporality of the organizational dynamics of appropriation of spaces, and discuss the different arrangements and combinations over time. Other possibilities lie in the understanding of these spatial dynamics in other organizational contexts, focusing on their relationships with urban spaces, in order to understand the symbolic relationships in the context of Brazilian cities.

\section{ACKNOWLEDGEMENTS}

Acknowledgements to the Foundation for Research and Innovation of Espírito Santo - FAPES (FAPES no. 006/2014 - Universal - Individual research project) and the National Council for Scientific and Technological Development - CNPq (Process $n^{\circ} 446524$ / 2014-0) for the financial support.

\section{REFERENCES}

BEYES, T.; STEYAERT, C. Spacing organization: non-representational theory and performing organizational space. Organization, v. 19, n. 1, p. 45-61, 2011.

BUCHANAN, I. Introduction. In: WARD, G. (ed.). The Certeau Reader. Oxford: Blackwell Publishers Ltd., 2000. p. 97-100.

CAIRNS, G.; McINNES, P.; ROBERTS, P. Organizational space/time: from imperfect panoptical to heterotopian understanding. Ephemera: Critical Dialogues on Organization, v. $3, \mathrm{n}$. 2, p. 126-138, 2003.

CARLOS, A. F. A. 0 espaço urbano: novos escritos sobre a cidade. São Paulo: Labur, 2007. CARRIERI, A. et al. Os espaços simbólicos e a construção de estratégias no Shopping Popular Oiapoque. Cad. EBAPE.BR, Rio de Janeiro, v. 6, n. 2, Jun. 2008.

CARRIERI, A.P.; SOUZA, M.M.P.; LENGLER, J. A Dimensão identitária em duas feiras hippies: uma comparação entre Estados Unidos e Brasil. Gestão.Org, v. 2, n. 9, p. 409 - 437. Mai/Ago 2011.

CAVEDON, N. R. Antropologia para administradores. Porto Alegre: EdUFRGS, 2008.

. Método etnográfico: da etnografia clássica às pesquisas contemporâneas. In: SOUZA, E. M. (org.). Metodologias e analíticas qualitativas em pesquisa organizacional: uma abordagem teórico-conceitual. Vitória: EDUFES, 2014. p. 65-90.

CERTEAU, M de. A invenção do cotidiano: 1. Artes de fazer. Tradução de Ephraim Ferreira Alves. $22^{\mathrm{a}}$ Ed. Petrópolis, RJ: Vozes, 2014. 
CHANLAT, J. F. Space, organisation and management thinking: a socio-historical perspective. In: CLEGG, S.R; KORNBERGER, M. (eds.). Space, organizations and management theory. Liber \& Copenhagen Business School Press, 2006. p. 17-43.

CHIESA, C.D.; FANTINEL, L.D. "Quando eu vi, eu tinha feito uma etnografia": notas sobre como não fazer uma "etnografia acidental". In: ENCONTRO DE ESTUDOS ORGANIZACIONAIS DA ANPAD, VIII, 2014. Anais... Gramado:ANPAD, 2014.

COVA, V. Lefebvre et de Certeau: la sociologie du quotidien. Cormelles-le-Royal: EMS, 2014.

CLEGG, S.R.; KORNBERGER, M. Introduction: rediscovering space. In: CLEGG, S.R.; KORNBERGER, M. (eds.). Space, organizations and management theory. Liber \& Copenhagen Business School Press, 2006. p. 8-16.

DALE, K.; BURRELL, G. The spaces of organisation \& organization of space: power, identity \& materiality at work. New York: Palgrave, 2008.

DAMASCENO, F. J. G. As cidades da juventude em Fortaleza. Revista Brasileira de História, São Paulo, v. 27, n. 53, p. 215-242, 2007.

DAMERON, S.; LÊ, J.K.; LEBARON, C. Materializing Strategy and Strategizing Material: Why Matter Matters. British Journal of Management, v. 26, p. s1-s12, 2015.

DE SOUZA, M. M. P. et al. Do "beija e deixa" ao "membro virtual": os vários usos do sagrado na Feira do Jubileu de Congonhas. Revista de Administração, v. 49, n. 2, p. 429-440, 2014.

DOVEY, K. Framing Places: mediating power in built form. London: Routledge, 1999.

ELDEN, S. Understanding Henri Lefebvre: theory and the possible. London: Continuum, 2004.

FERRETTI, M. Feiras Nordestinas - Estudos e problemas. In: FERRETTI, S. (org.). Reeducando o olhar: estudos sobre feiras e mercados. São Luis, Maranhão: Edições Universidade Federal do Maranhão/Proin-CS, 2000. p. 36-66.

FILGUEIRAS, B.S.C. Do mercado popular ao espaço de vitalidade: o Mercado Central de Belo Horizonte. Dissertação (Mestrado em Planejamento Urbano e Regional) - Universidade Federal do Rio de Janeiro, 2006.

FISCHER, G. N. Espaço, identidade e organização. In: CHANLAT, J.-F. (coord.). 0 indivíduo na organização: dimensões esquecidas. v. 2. São Paulo: Atlas, 1994.

FISCHER, T. A cidade como teia organizacional: inovações, continuidades e ressonâncias culturais Salvador, BA, cidade puzzle. RAP - Revista de Administração Pública. v. 3, p. 74-88. Rio de Janeiro, 1997.

FLEMING, P.; SPICER, A. Power in management and organization science. Academy of Management Annals, v. 8, n. 1, p. 237-298, 2014.

GIBLER, K.M.; BLACK, R.T.; MOON, K.P. Time, Place, Space, Technology and Corporate Real Estate Strategy. Journal of Real Estate Research, v. 24, n. 3, p. 235-62, 2002. 
HATCH, M. J.; CUNLIFFE, A. Organization Theory: modern, symbolic, and post-modern perspectives. Hampshire: Oxford University Press, 2013.

HERNES, T. The spatial construction of organization. Amsterdam: John Benjamins Publishing, 2004.

IBGE. Censo 2010. Disponível em: <http://legado.vitoria.es.gov.br/regionais/home.asp>. Accessed Mar. 28, 2015.

IPIRANGA, A.S.R. A cultura das cidades e seus espaços intermediários: os bares e os restaurantes. RAM - Revista de Administração Mackenzie. São Paulo, v. 11, n. 1, p. 65-91, 2010.

KERR, R.; ROBINSON, S. K.; ELLIOTT, C. Modernism, Postmodernism, and corporate power: historicizing the architectural typology of the corporate campus. Management \& Organizational History, v. 11, n. 2, 2016, p. 123-146.

KIPFER, S. et al. On the production of Henri Lefebvre. In: GOONEWARDENA, K. et al. Space, difference, everyday life: reading Henri Lefebvre. New York: Routledge, 2008, p. 1-25. KORNBERGER, M.; CLEGG, S.R. Organising Space. In: CLEGG, S.R; KORNBERGER, M. (eds.). Space, organizations and management theory. Liber \& Copenhagen Business School Press, 2006. p. 143-162.

LEFEBVRE, H. A produção do espaço. Trad. Doralice Barros Pereira e Sérgio Martins. $1^{\text {a }}$. v. 2006. (original: La production de l'espace. 4e éd.Paris: Éditions Anthropos, 2000)

MOTT, L. R. B. Subsídios à história do pequeno comércio no Brasil. Revista de História, São Paulo, ano 27, n. 105, p. 81-106, 1976.

. Feira e mercados: pistas para pesquisa de campo. In: FERRETTI, S. (org.). Reeducando o olhar: estudos sobre feiras e mercados. São Luis, Maranhão: Edições Universidade Federal do Maranhão/Proin-CS, 2000. p.13-34.

O'TOOLE, P.; WERE, P. Observing places: using space and material culture in qualitative research. Qualitative Research, v. 8, n. 5, p. 616-634, 2008.

PINHEIRO-MACHADO, R. Made in China: produção e circulação de mercadorias no circuito China-Paraguai-Brasil. 2009. $332 \mathrm{f}$. Tese (Doutorado em Antropologia) - Programa de Pós-Graduação em Antropologia Social, Universidade Federal do Rio Grande do Sul, Porto Alegre, 2009.

PIMENTEL, T.D. et al., As representações e as práticas sociais das "sacoleiras" na feira hippie de Belo Horizonte: A representação social de empreendedoras de pequenos negócios. Revista da Micro e Pequena Empresa, Campo Limpo Paulista, v. 5, n. 2, p. 60-76, 2011.

PIMENTEL, T. D.; CARRIERI, A.P.; LEITE-DA-SILVA, A.R. Ambiguidades identitárias na "Feira Hippie"/Brasil. Comportamento organizacional e gestão, v. 13, n. 2, p. 213-236, 2007.

PUTNAM, L. L.; BANGHART, S. Interpretive Approaches. In: SCOTT, C.R.; LEWIS, L. (eds.). The International Encyclopedia of Organizational Communication. Hoboken: Wiley-Blackwell, 2017. 
ROPO, A., HÖYKINPURO, R. Narrating organizational spaces. Journal of Organizational Change Management, v. 30, n. 3, p. 357-366, 2017.

SANTOS, M. Natureza do Espaço: técnica e tempo, razão e emoção. São Paulo: Editora da Universidade de São Paulo, 2006.

SATO, L. Processos cotidianos de organização do trabalho na feira livre. Psicologia \& Sociedade, v. 19, ed. especial, p. 95-102, Porto Alegre, 2007.

SOUSA, A.M. A feira livre na Cohab: contatos iniciais com a realidade da feira do produtor rural em São Luís. In: FERRETTI, S. (org.). Reeducando o olhar: estudos sobre feiras e mercados. São Luis, Maranhão: Edições Universidade Federal do Maranhão/Proin-CS, 2000, p. 67-96.

TAYLOR, S.; SPICER, A. On organizational spaces time for space: a narrative review of research on organizational spaces. International Journal of Management Reviews, v. 9, n. 4, p. 325-346, 2007.

TOMKINS; L.; EATOUGH, V. The feel of experience: phenomenological ideas for organizational research. Qualitative Research in Organizations and Management: An International Journal, v. 8, n. 3, p. 258-275, 2013.

VALAND, M. Between organisation and architecture: end-user participation in design. International Journal of Work Organisation and Emotion, v. 4, n. 1, p. 42-60, 2011.

VAN MARREWIJK, A.; YANOW, D. The spatial turn in organizational studies. In: (eds.). Organizational Spaces: rematerializing the workaday world. Cheltenham: $\overline{\text { Edward }}$ Elgar, 2010, p. 1-15.

VÁSQUEZ, C. A spatial grammar of organising: studying the communicative constitution of organisational spaces. Communication Research and Practice, v. 2, n. 3, p. 351-377, 2016.

VAUJANY, F.; MITEV, N. Introduction: Space in Organization and Socio materiality. In:

(eds.). Materiality and spaces: Organizations, Artifacts, and Practices. Hampshire and New York: Palgrave Macmillan, 2013, p. 1-23.

VIEGAS, G. C. F. S.; SARAIVA, L. A. S. Discursos, práticas organizativas e pichação em Belo Horizonte. Rev. Adm. Mackenzie, v. 16, n. 5, São Paulo, 2015.

VITÓRIA (município). Vitória em dados. Secretaria de Gestão Estratégica / Gerência de Informações Municipais: Vitória, 2015. Disponível em: <http://legado.vitoria.es.gov.br/ regionais/home.asp>. Accessed April 2, 2015.

WATKINS, C. Representations of space, spatial practices and spaces of representation: an application of Lefebvre's spatial triad. Culture and Organization, v. 11, n. 3, p. 209-220, 2005.

WILHOIT, E. D. Organizational Space and Place beyond Container or Construction: Exploring Workspace in the Communicative Constitution of Organizations. Annals of the International Communication Association, v. 40, n. 1, p. 247-275, 2016. 
WILSON, J. The Devastating Conquest of the Lived by the Conceived: The concept of abstract space in the work of Henri Lefebvre. Space and Culture, v. 16, n. 3, p. 364-380, 2013.

Submission date: 09/13/2016.

Approval date: 08/24/2017.

(c) (1)

Creative Commons Atribuição 4.0 Internacional

Note: you can find this paper in Portuguese at http://www.revistaoes.ufba.br. 